\title{
Eliciting Children's/Young People's (Group) Engagement with Scenarios as Participatory Research Practice for Exploring and Extending Responses to Climate Change
}

\author{
Norma R.A. Romm* \\ Department of Adult Education and Youth Development, University of South Africa, \\ ORCID: 0000-0002-1722-9720
}

\begin{tabular}{|c|c|}
\hline & \multirow{7}{*}{$\begin{array}{l}\text { In this article I provide an account of my use (in a particular } \\
\text { context) of a 'post qualitative inquiry' approach, with my } \\
\text { recognition that ways of approaching issues to be explored with } \\
\text { participants, and the method of exploration, carry social and } \\
\text { ecological consequences. The research was initiated in a school in } \\
\text { South Africa with a sample of ten (Black) Grade } 9 \text { children (aged } \\
\text { 14-15). Groups of two to three children engaged with a number of } \\
\text { scenarios supplied by me ('business as usual', 'small changes', and } \\
\text { 'sustainable future') concerning possible responses to climate } \\
\text { change. In each group the children worked together towards jointly } \\
\text { creating options for unsettling the 'business as usual' scenario } \\
\text { while exploring the other scenarios as alternatives. The article } \\
\text { concentrates on the justification for using scenarios as a basis for } \\
\text { inviting the children to discuss together their responses to climate } \\
\text { change, with a view to the research inputting into their visioning } \\
\text { and their understandings of possibilities for agency (individual and } \\
\text { collective). It also concentrates on my intent to strengthen the } \\
\text { notion of collaborative visioning, which is in keeping with } \\
\text { Indigenous understandings of relational knowing. The research } \\
\text { was intended, inter alia, to contribute to the children's appreciation } \\
\text { of this way of learning. }\end{array}$} \\
\hline & \\
\hline & \\
\hline & \\
\hline & \\
\hline Key words: & \\
\hline & \\
\hline
\end{tabular}

\section{Introduction}

This article details a research encounter with children in a school in South Africa, in which I was mindful that research endeavors are never neutral in their social and ecological consequences. For instance, research can serve (wittingly or unwittingly) to buttress what Jones calls 'modernist/capitalist' visions of people as separate entities who then (as separate selves) interact with one another and with other 'entities' in the course of social life, or it can be oriented (in transgressive fashion) to try to explore counterpoints to these visions (2008, p. 202).

St. Pierre explains that in post qualitative inquiry the idea is to use the research process to 'encourage concrete ... creation of the not yet' $(2019$, p. 3$)$. This echoes Jones's argument that 
'the ... movements of the becomings of everyday life are simply missed by established social science ontologies, epistemologies and methodologies', which seek to 'represent apparently settled structures' (2008, p. 202). Jones suggests that research with children (in terms of nonrepresentational thinking) could function to draw out the transgressive capacities of children in relation to 'striations of adult society' (2008, p. 202).

The research approach as recounted in this article points to an innovative approach to research in this vein, as undertaken with Black school children (aged 14-15) in a selected school in a relatively disadvantaged social area in South Africa, in relation to sustainable development. I explain how I made use of three scenarios that had been developed by McIntyre-Mills during a research project in Australia, which was sparked with Aboriginal participants and was continued with a local government in South Australia (McIntyre-Mills, 2014a,b; Romm, 2018). I asked the children to focus, in dialogue with one another, on possible futures in the South African context in reflecting upon the possible relevance of the scenarios for this context. (In a related article, Romm, 2020, I focus on the ethical implications of the approach that I adopted in relation to the children, in the light of wider debates on research ethics.)

\section{Rationale for Supplying Scenarios as a Trigger for Discussion}

In keeping with Ulmer's account of non-representational research practices (2017, p. 838), I was attempting to 'produce something different, something generative' rather than purporting to 'represent' children's static and pre-given understandings, outside of the relations between each other and with myself as provider of the scenarios. My intention in setting up the scenario exercise is that it could prompt the children to generate (anticipatory) visions together, while experiencing processes of collaborative learning/knowing as relational knowing (in relation to each other and to the supplied scenarios).

I consider the approach to be an innovative one in research with children, as there is scant literature on use of scenarios as part of the repertoire for participatory research with children (whom some authors prefer to call 'young people' when they are 14-18 years - cf. Campbell, Skovdal, \& Campbell, 2013; Hill, 2006; Jones, 2008; Rousell \& Cutler-Mackenzie-Knowles, 2019; Skelton, 2008). The literature to date focuses on invoking participation with various age groups through exercises such as mapping, spider diagramming, completing charts and diagrams, collage, children-led photography, role play exercises, story-telling, and story writing (as noted by Broström, 2012; Gallagher, 2008; Somerville \& Williams, 2015).

A recent example of inviting construction of scenarios with young people was set in South Africa. This research adopted a social constructionist approach to explore children's constructions of reality (Nkoana, 2019, p. 8). Nkoana used 'future-backwards' scenario mapping in focus group discussions with children aged 13-15 years (one with township and one with rural children), asking them to consider the current situation, compared with a worst case scenario and a best case scenario in relation to concerns they may have. But apart from the work of Nkoana (2019) the possibility of using scenario-based research with children seems not to have been capitalized upon. My specific way of working with scenarios differs somewhat from that of Nkoana (2019, p. 1) in that I offered a set of (written) scenarios to the children, to spark off, and hopefully enrich, their thinking/feeling around climate change (CC) concerns.

It is important to note that in my approach, I concur with St. Pierre that in post qualitative inquiry, one does not start with a 'research question', but rather with what she terms 'a concrete encounter with the real' $(2019$, p. 12). Notably for her, 'the real' is not to be seen as something given, which the employment of 'research method(s)' will help to 'find', but as always in-the- 
making. In Romm (2018), I suggested likewise that in considering our way of proceeding in the research space, professional researchers need to be mindful of how we address our responsibilities (and co-responsibilities with others) for the potential unfolding of the social and ecological worlds being explored. This also implies that, like Gallagher (2008, p. 143), I do not consider power as being a 'commodity' which people (such as professional researchers or research participants) 'have'; rather, the idea was to organize relations of power such that shared learning could ensue as part of the co-research process (see also Flood \& Romm, 2018, p. 266 in this regard).

Considering the African context, Msila (2017, p. 56) strongly states that sharing (including sharing of understandings as part of the collective knowing process) is an African obligation. This implies that those initiating research explorations need not desist from inputting into conversations as part of the discussion/exploration. In this case my input was largely through my supply of the scenarios (for the children/young people to engage with).

Before I begin the discussion, I should mention that my encounter with the children as reported upon in this article is part of a larger community-engaged research project organized through my university, with the school and surrounding areas. In this article I am concentrating only on the encounter with the Grade 9 children (aged 14-15) in the selected school.

\section{Brief Background to My Involvement with the School}

The school, named Tiger Kloof (which the director is pleased to be named and acknowledged in research write ups) is situated in a town called Vryberg in the North West Province of South Africa. My involvement with the Tiger Kloof school has been through one of the past deputy principals - namely, Arko-Achemfuor. He is now a colleague in the university where we both work. Arko-Achemfuor, other colleagues, and I have been working on community engagement projects primarily with an alumnus of the school, in setting up ecofriendly and sustainable co-operative rural development projects in nearby villages. As part of our community-engaged research we have been liaising with the farm manager at the school (henceforth called MM), who focuses on care for the environment, a care which he tries to encourage in others. He teaches the Grade 8 and 9 children environmental management as part of the geography curriculum. The school also benefits from the Eduplant program, which for many years has been supported by Woolworths (a private sector company). Eduplant is managed by the NGO called Food \& Trees for Africa (FTFA) that teaches permaculture food gardening programmes in under-resourced schools (see https://trees.org.za/the-eduplantprogramme-launches-its-next-cycle-of-support/).

In October 2018, Arko-Achemfuor (nicknamed Arko) and I visited one of the communities in which the alumnus mentioned above is operating. (Please see Arko-Achemfuor, Romm, \& Serolong, 2019 for details.) On our way back to Pretoria we visited Tiger Kloof. After speaking briefly to MM about, inter alia, how his work with the children was going I mentioned that I had an exercise which I thought could be fruitful for some of them to participate in doing based on scenarios that had been developed in the Australian context, which express different responses to $\mathrm{CC}$. He concurred that this seemed a good idea as it would be another way of stimulating the children to think about $\mathrm{CC}$ responses.

When I mooted the idea with the director, she indicated that said she could seek volunteers from the Grade 9 geography class; and subsequently I met with ten volunteers in a classroom. (Arko was meanwhile speaking to the building manager regarding a project for setting up biodigesters.) I asked the children why they had volunteered and they said that most of them 
were in the Eduplant program - some had been with it for a long time and some for less time, but this is why they wanted to participate as the topic sounded interesting. I explained that I was a researcher and wanted to hear from them how they considered the applicability in South Africa of certain scenarios that another researcher had developed with others in Australia, and that I was hoping that through the exercise they could learn from one another too.

\section{Method: The Scenario Exercise}

In presenting the suggested exercise to the children (showing them that I had copies of written sheets outlining three scenarios), I indicated that the exercise was meant for them to look at the scenarios as formulated in Australia (by McIntyre-Mills) and to consider their possible relevance when thinking together about responses to $\mathrm{CC}$ in South Africa. (Please see Appendix A for the scenarios.) I mentioned briefly that the 'business as usual' scenario implies a way of thinking and living where people focus on economic aspects of life and tend to treat as unimportant the social and environmental aspects. (I had seen that the South African geography curriculum for Grade 9 referred to these three aspects when addressing 'development'.) I mentioned that the 'small changes' scenario implies that people (also via government and NGO initiatives) try to embrace some change in relation to social and environmental issues, for the benefit of future generations too. And I explained that in the 'sustainable future' scenario, people are even more prepared, through increased initiatives, to face up to the challenges of CC. I suggested that in their looking at the outline of the three scenarios, they should discuss together (in groups) their possible application in South Africa.

I explained that they had about an hour to complete the exercise - which involved their writing down their joint thoughts. I asked them how many groups they thought it would be best to divide themselves into; and they suggested two groups of two and two groups of three. They then selected their 'partners' and organized to sit in different parts of the classroom.

I supplied them with the scenarios along with sheets of paper and pens and asked them to write their names on the sheets only for purposes of my remembering the different groups and not for any other purpose, as this would remain anonymous. While they were busy talking and writing, I went around to each group asking them if they found any of the words or phrases in the scenarios needed further explaining by me. One of the groups spotted the phrase 'status symbol' and asked me what this meant. It was in the scenario called 'a sustainable future scenario'. One of the sentences was: 'The new status symbol is the environmentally friendly lifestyle'. I explained to this group (and later decided to explain it also to the other groups as I realized this may be an unfamiliar phrase to them) that, for instance, Nelson Mandela (whom of course they all knew) said that people can gain respect and status in the community other than by trying to seek and display material wealth.

After about 40 minutes had passed, I went to each group in turn asking the children if they thought they were learning from each other while doing the exercise. (I asked them if I could tape their responses so that I could remember what they had said to me, and they all agreed). While asking them about their learning together, I was (implicitly) trying to support the practice of relational knowing. As Chilisa, from an Indigenous African perspective explains, 'knowing is something that is socially constructed by people who have relationships and connections with each other, the living and the nonliving and the environment' (2012, p. 116).

It is also worth highlighting at this point that clearly the scenarios, and my brief explanation of them that I furnished orally, were not neutral in content. As emphasized by myriads of researchers - especially those who self-name themselves as working in terms of post 
qualitative, transformative, and Indigenous understandings of the research process - research willy nilly impacts on the social worlds of which it is a part (cf. Bubar \& Martinez, 2017; Chilisa 2012, 2017; Colliver et al., 2015; Dei, 2012; Denzin \& Giardina, 2007; Denzin \& Lincoln, 2008; Flood, 2010; Gergen, 2009, 2015; Kuntz, 2015; Le Grange, 2018; Lincoln \& Guba, 2013; Mertens, 2010, 2019; Midgley, 2001; Nicholls 2009; Rajapolan \& Midgley, 2016; Romm, 2001, 2015, 2018; Smith, 1999; Spyrou, Rosen, \& Cook, 2018). As Kuntz succinctly puts it, 'engaging in inquiry practices always affects the phenomena of interest-we can never not impact that which we study' (2015, p. 65). For this reason, (professional) researchers need to be mindful or how they are framing the issues to be explored. Nkoana refers in this regard to the general agreement of '(climate risk) communication scholars' that 'positive frames encourage feelings of efficacy and negative frames induce powerlessness to do anything about the wicked problem of climate change' $(2019$, p. 71$)$. He also points to the importance of adopting an 'asset-based' community development approach to guide research, as an approach geared to highlighting 'local [transformative] capacities'. This is consistent with the exhortation of Chilisa for researchers to resist deficit research approaches which are debilitating in effect (2012, p. 174).

In the light of these considerations I would suggest that the 'scenario method' in the way in which I used it (with some differences from Nkoana's approach in that I provided some 'prompts' through the supplied scenarios) became a promising way of proceeding, as also reflected in the manner in which the children 'took to it', as discussed in the section below. (Roth, 2006, paragraphs 26-28, emphasizes that while one can assume some responsibility for the way in which one tries to set up social encounters and for the way in which they might pan out, responsibility is ultimately a collective one and depends on how other actors relate to - or 'complete' - the turns that one performs, including in the research context.)

\section{A Narrative Analysis: The Children's Notes and My Storying around Them}

In the discussion below I have named the groups as A, B, C, and D-with groups A and $\mathrm{B}$ being the groups of two children, and groups $\mathrm{C}$ and $\mathrm{D}$ being the groups of three children. For purposes of trying to do justice to the flow of each group's deliberations, I am not going to break this flow by looking for 'themes' across the groups and finding examples of statements that offer 'evidence' of the appearance of the themes. This style of write up is also criticized by St. Pierre $(2019$, p. 7). While I venture to make some comparisons across groups in relation to the notes of the children, my 'analysis' is more akin to what Cohen, Manion, and Morrison (2011, p. 552) call a 'narrative style' of write up.

In regard to the Business as Usual scenario, all four of the groups stated in their notes words to the effect that the (vast) majority of South Africans think and act in terms of 'business as usual', which amounts to concentrating on economic considerations and ignoring social and environmental ones. As Group A put it: 'People in South Africa tend to ignore the social and environmental dimensions'. Group A suggested that acting in terms of the 'business as usual' scenario could be attributed partly to people's lack of awareness of the (deleterious) impact of humans on the environment. They surmised that: '90\% of the people in South Africa are not aware of the impact they have on the environment'. (Their geography curriculum by definition deals with the impact of humans on the physical environment; so they themselves consider that they are more aware.) As will be seen below, they felt that one of the options for change could be to increase people's awareness across the society. They also considered when discussing the sustainable future scenario that attempts to increase awareness should be coupled with attention to 'try to change the mentality people have towards nature'. 
The 'mentality towards nature' was associated by them (in their notes as a whole) with a love of nature for its own sake - and not necessarily just for the sake of human wellbeing in the sense that if we don't respect nature her resources will run out for future generations. This ethos was also expressed when they commented in relation to the 'slow changes' scenario that some people choose to 'pick tins and plastic bottles around' and place these in the (municipalitysupplied) separate containers. These (two) children stated that they believe people choose to do this 'for the love of the environment'. This was the only group that used the word 'love' in relation to the environment. But I would regard it as significant that they did indeed use the word, thus expressing what some authors - such as Le Grange (2018), McIntyre-Mills (2014b, 2017), Osuji (2018), Romm (2017), and Stephens, Taket, and Gaglioano (2019) - call a nonanthropocentric ethic.

Returning to Group A's deliberations, as far as the 'slow changes' scenario in South Africa is concerned, they noted that 'we have organizations such as Edu-plant. Edu-plant is an organization that motivates young children to take care of environment and its resources. There are also organizations like Woolworths [a business] that help financially by giving funds to the Edu-plant and the trees for Africa. The trees for Africa hold workshops in communities responding to local environmental changes'. Their reference to these organizations also springs from the involvement of these organizations in their school- as I mentioned in my background to the Tiger Kloof institution. This shows (to me) that these organizations are making an impression on these children and giving them some sense that there is collective co-ordination of action in which they are (and can be) involved as part of the school.

But they felt that for a sustainable future, more is needed. As they stated - while acknowledging that this was their joint opinion (our opinion) and also that there may be other opinions in the social fabric - 'Our opinion for a sustainable future is building affordable houses made of suitable materials, grow organic and safe food. Make people more aware of the impact they have on the environment and do what we can to prevent global warming and climate change. Do more of recycling and also try to change mentality that people have towards nature'. Their reference to affordable houses here refers to materials that are eco-friendly (as in the scenarios supplied) and their reference to organic and safe food resonates with some of our conversations with MM, in which he referred to his break with 'conventional' farming which uses pesticides and herbicides.

Group B in their engagement with the different scenarios also considered, like Group A, why people - whom they also thought were the vast majority, 70\% - are not taking sufficient heed of $\mathrm{CC}$ and are continuing with Business as Usual. When considering the Business as Usual scenario, Group B started by stating that 'People feel like it's less important to look after our environment as effects are not that visual, E.g., we are told every day that global warming is increasing and dangerous in South Africa but no-one seems to be taking note of it'. Group B considered that although 'we [South Africans] are 'told every day' about the dangers of CC, people can consider this not important especially as they cannot easily 'see' the effects. The effects are not sufficiently visible. They stated that 'we [those doing Business as Usual] don't even realize the CC in our country and seasons change in a very weird way. Our weather is abnormal and we rarely get rain in South Africa'. Here they introduced the idea that a narrow 'empiricism' (relying on what seems to be visible) as a way of knowing does not allow for more holistic appreciation of the link between human activity and CC. But they also added that besides people not seeming to notice the effects of $\mathrm{CC}$ (so that they can regard the dangers of $\mathrm{CC}$ as 'less important'), those enacting the Business as Usual Scenario 'don't care about what will happen in the future'. They thus introduced a critical comment about people's not caring 
sufficiently about future generations.

Regarding the Small Changes scenario, they estimated that about $15 \%$ of people 'manage to make a small change, but to sustain for a period of time only'. They used the example of farming and stated that people 'only farm for themselves and don't do it for everyone'. They also stated that in fishing, people 'fish more than they should and only cause further damage to the environmental marine life'. Again their critical commentary meant that they wondered about whether this scenario could lead to a sustainable future.

Considering a Sustainable Future, they estimated that a very small proportion of people in South Africa are thinking and acting along these lines. As they stated: 'About $5 \%$ of people in South Africa care about the next future generation'. Here again they pointed to people for the most part not caring about the future generation. In regard to those who do care, they considered that 'most of these people are in environmental clubs or are either teachers or environmentalists'. And they commented that for a sustainable future more people need to show concern: 'In order to sustain future generations our communities need to take note of the dangers that our environment is facing'. They recognized that this required community (collective) agency. But their notes ended on a somewhat less hopeful note: 'People are selfish and only take good care of themselves'.

Group C started their notes with 'key factors' that needed to be addressed during the exercise - human rights, respecting biodiversity, and hope for the future. They thus decided upfront to focus, inter alia, on hope. In considering the Business as Usual scenario, they suggested that people who do not participate in this scenario, that is, people "who really take notice of climate, environment and social factors in South Africa, are usually only the ones who are a partaking in agriculture'. They thus drew a distinction between industry (and those in industry who 'ignore pollution or increase pollution') and people in the rural areas (who contribute less to this). They tried to explain why 'in the country of ours global warming has increased since 2008 ' by suggesting that 'from a perspective this could be that they [those contributing most to $C C]$ are unaware of the effects and how their actions are not benefitable to the environment'. (The idea that people following a 'business as usual' route might be doing so partly due to 'lack of awareness' (Group A), or due to effects being 'not that visible' (Group B), or again because humans perhaps are 'unaware of the effects' of their actions (Group C), and as will be seen below because 'citizens won't notice much of the effects of their doings' (Group D), was a way of explaining the prevalence of this scenario as estimated by all the groups.)

For the Small Changes scenario, Group C located different kinds of 'routes' that might be taken in this scenario, by referring to different types of people (or people in different domains of social life). Following from their suggestion that 'agricultural people' are less likely than industrialists to contribute to a Business as Usual scenario, they stated that the 'first type of people' in the Small Changes scenario are: 'The agriculture people, because they are aware of the environmental impacts and how change can work for the better. They are also the ones who mostly have a say in what is agreed on in agricultural environmental changes'. Notably, Group $\mathrm{C}$ stated that the agricultural people (perhaps due to their school's linkages with neighboring rural villages in terms of environmental awareness) are more aware of how change can work for the better; and also they presumed that because these people have more of a say in decisions in regard to change, they are more amenable to this. They also identified a second 'type of people' - those that are 'follow the leader' type of people who 'go with the flow' and 'slightly have knowledge' but mainly they don't try to have a say in what is changeable. (This implies that if leaders in the community/society set a good example towards enacting change, these 
people will probably follow.) They identified a third 'type of person' who are 'just living because they are there'. They clarified that: 'All they think of is pursuing money and living a status life'. (This was their way of engaging with my having tried to explain to them about status often being associated with wealth.) They added also a 'fourth type of person - don't want change'. They noted that: These are the people that are comfortable and relaxed in the way that the environment, global warming and social issues present themselves. They feel it is not worth a change'. Altogether, with all these different types of people as part of the 'slow change' scenario, they concluded that 'this is why changing factors is really difficult in South Africa'.

They noted some hope for change when they discussed the Sustainable Future scenario. They considered that future-directed thinking (coupled with increased awareness) could be germinated/strengthened because, as they put it, 'People in South Africa have 'science projects' called 'science expo'. These train young children to choose change and make a difference in the environment'. They thus considered that 'young children' can become agents of change (through being supported in this in their education, such as science education run by 'science expo').

Group D also felt that education was helpful - e.g., via the activities of Edu-plant, which has a presence in their school. Like the previous groups, when referring to the Business as Usual scenario, Group D made sense of its prevalence (which they estimated as $70 \%$ of people 'agreeing with') by suggesting that people may not notice their impact on the environment. They stated it thus: 'The climate in South Africa does not change rapidly so as to cause droughts, floods and other natural disasters so our citizens won't notice much effects of their doings'. They compared this with the Australian context by referring to the more advanced level of industralization of Australia and its consequent impact on the environment, making it difficult to ignore in that context. This was the only group that explicitly mentioned a comparison with Australia: 'The reason the citizens of Australia are witnessing dramatic climate change is because the industries are more developed than ours and faster'. But they noted that in South Africa, there are industries responsible for causing environmental changes, which leads to 'us' (South Africans) experiencing 'the rise in the hot temperatures during our summers due to the increasing of greenhouse gases into the atmosphere released by industries operated by us humans causing the ozone layer to decrease'. They suggested that 'the scenario won't help South Africa, so we won't suggest its application'.

In their notes regarding the Small Changes scenario, they referred to some initiatives taken by the South African government: 'The South African government has taken the initiative to travel in schools encouraging recycling and gardening. For the schools that took note of this they have seen the change'. They point here to the mutuality needed in terms of relations between the government and schools - government efforts need to be translated into continuing practice in the schools for change to occur. They commented that what is causing 'slowness' of the pace of change is that 'The people of South Africa keep postponing the changes as said on the [supplied] scenarios, their level of thinking is very slow. Despite the measures taken by the government many turn their backs [on CC] and remain to be ignorant'. In more hopeful vein, they advised that: 'The small changes applied should be as many as possible so as to make a difference including planting trees. Distribution of more free water tanks [rain water collection] and biofuel operated cars'.

Under the heading of a Sustainable Future scenario, they remarked that: 'The country of South Africa will not be able to support the next generation with electricity as coal would have run 
out'. They expressed concern that ' $80 \%$ of our power is coal because the renewable resource is not enough to cover the whole country'. But they concluded that 'South Africa is well educated about the environment thanks to Edu-plant so we think about $60 \%$ of the population would confer'. (Their statistics did not add up as they had stated that about $70 \%$ of the population fall under the Business as Usual scenario - but they could be interpreted as meaning here that with more education, more people might shift into enacting the Sustainable Future scenario in a future 'yet to be'. St. Pierre - in her account of post qualitative inquiry (2017, 2019) - might suggest that the numbers do not need to add up if one is considering the 'yet to be' as part of the world-in-the-making.)

\section{The Children's Stated Learning from the Process}

To strengthen the children's appreciation of the value of collaborative thinking and imagining in relation to responses to CC, I went around to each group after about 40 minutes had passed, asking each of the children what, if anything, they thought they had learned from their partners during the group work. Space does not permit a detailed account of our encounters, but suffice it to say that all of the children stated what they felt they had learned.

Examples given by the children in Group A centred on their having become more alert to what was being done in the community. For instance, the one learner in Group A stated that her partner had helped her to 'think how some people are working for change. She thought of programs that we could use [in our notes here] e.g., trees for Africa'; while her partner stated that she had helped her to "learn that in our local area in the townships there is litter that is being recycled'.

The children in Group B focused more on how they had shared ideas about 'how the environment is getting damaged' in answer to which I asked (rhetorically, as a way of adding into their discourse) whether they had also spoken about what can be done in future, to which they replied 'yes' (but this could have been more because I had prompted them in this direction, which indeed I had consciously done!)

The three children in group $\mathrm{C}$ indicated (in turn) that they had learned that the three of them had different perspectives regarding CC: they had learned that one of them tended more to the 'business as usual' side of thinking, while the other 'wants some slow change' and the other wants to move more quickly to 'sustainable development' (which shows that at least they had become aware of differing perspectives that could be held, and the possibility of still co-creating visions together, as indicated by their notes).

The three children in Group D indicated that together they had come up with a range of ideas on how to address the environment. One learner stated this as follows: 'We are talking about what some of us think about the environment of South Africa. We are coming up with different ideas. We are also thinking about how we can include our parents'. Here she indicated that they had come up with a range of ideas in relation to dealing with environmental concerns, including the idea of invoking their parents as part of a collective effort. Another learner clarified that 'We are thinking [together] about how as South Africans we can change the environment of South Africa'; while the third one said that she 'learned about how to work as a group' (most likely referring to the group work of that day, although she may have meant more generally how people could work collectively in groups).

In response to each of the children in each group I offered some input to affirm and also cast some new light on what they had said - as part of the conversation. But due to space limitations 
I will not record this here. (What can be said here, is that the brief feedback from the children provides some expression of their sense of co-generating together their visions regarding responses to $\mathrm{CC}$.)

\section{Conclusion: Summary of Potential Benefits of Asking Children to Engage with Scenarios}

To conclude, I draw together what has been a thread throughout this article, namely, what I consider to be some advantages of the suggested practice of using scenarios for participatory research with children, particularly in relation to $\mathrm{CC}$ concerns. I suggest that use of the 'scenario method' (adapted of course to address different research contexts and also used creatively rather than as 'rules') can add to the repertoire of methods that might be employed, in terms of the following epistemological and ethical justifications:

- By suggesting to the children that I was hoping that I could learn from them by seeing how they were engaging with, and reconsidering, the (Australian-derived) scenarios, I could implicitly affirm that their perspectives were worthy of consideration as an entry into all of our thinking about CC responses. They thus could become - and could consider themselves as being - co-researchers.

- By suggesting to the children that the point of the exercise was not that I (as researcher) could 'find out' their thoughts/views/feelings but that I was more interested in how they were working together and learning from each other when speaking about the scenarios, I could subvert for them (again implicitly) the notion that research is an extractive enterprise where (static) views become 'extracted'.

- By indicating to the children that I was hoping they could learn from each other and also would find the scenarios a fruitful way of triggering their discussion, I could practice what Indigenous research methodologists (e.g., Chilisa, 2012; 2017; Kovach, 2009) call reciprocity in the research relationship - by indicating that I was expecting that the children would find the exercise worthwhile and as being a learning experience for them as well as for me.

- By offering the presented scenarios - which clearly were not neutral in content - as a starting point to trigger discussion, I could spark off their ethical considerations as part of their explorations around $\mathrm{CC}$ responses. I could introduce a critical edge to the 'business as usual scenario' while providing an opportunity for the children to introduce values into their own discussions. By offering the (non-neutral) scenarios as a basis for discussion, I was able to do 'values-based' research (Shannon, 2013), which would be likely to spark further ethical considerations. In this way I implicitly tied epistemology (knowing) to a concern with ethics (the wellbeing of people and planet) without closing the discussion on 'just' social practices that the children might envisage.

- Because the scenarios include some possibilities for a 'sustainable future' (and invite discussion around this) deficit discourses which imply that communities do not have the assets to address 'problems' are undercut (as advised by Chilisa, 2012, 2017). Even though Group B chose to focus in their notes on damages being done to the environment, the scenario imagery I had provided allowed me to question them (by way of a rhetorical question) about whether they were also considering options for more forward-looking thinking - thus (potentially) inputting into their discourse in this way.

Interestingly, while Rousell and Cutter-Mackenzie-Knowles (2019, p. 1) point to literature suggesting that 'young people's understandings of climate change are generally limited', I would suggest that these children/young persons' responses, as generated through the relational 
encounters with each other and with the scenarios, points to quite sophisticated deliberations on their part. In the study conducted by Campbell, Skovdal, and Campbell (2013) using photovoice with young people (school students) in Ethiopia, the authors similarly conclude that 'thematic analysis of our findings suggest that young people have a deep appreciation of the moral, health related and economic importance of the environment, a commitment to preserving it, and agency in relation to continuing its preservation' (2013, p. 436). Further innovative and participatory research is needed to set up co-researching encounters (encouraging asset-based approaches to the framing of issues) with children/young people to explore together with their peers and with professional researchers, options for 'making a difference' in relation to climate change.

\section{References}

Arko-Achemfuor, A., Romm, N. R. A., \& Serolong, L. (2019). Academic-practitioner collaboration with communities towards social and ecological transformation International Journal of Transformative Research, 6(1):1-9.

Boström, S. (2012). Children's participation in research. International Journal of Early Years Education, 20 (3): 257-269.

Bubar, R., \& Martinez, D. E. (2017). Trickster as resistance: Impacts of neoliberalism on indigenous research and indigenous methodologies. In N. K. Denzin \& M. D. Giardina (Eds.), Qualitative inquiry in neoliberal times (pp. 136-150). New York, NY: Routledge.

Campbell, E., Skovdal, M., \& Campbell, C. (2013). Ethiopian students' relationship with their environment: Implications for environmental and climate adaptation programmes. Children's Geographies, 11 (4): 436-460.

Chilisa, B. (2012). Indigenous research methodologies. London: Sage.

Chilisa, B. (2017). Decolonizing transdisciplinary research approaches: An African perspective for enhancing knowledge integration in sustainability science. Sustainability Science, 12 (5): 813-27.

Cohen, L., Manion, L., \& Morrison, K. (2011). Research methods in education (7th ed). London: Routledge.

Colliver, R., Goff, S., Reedy, R., \& Vaartjes, V. (2015). Systemic pedagogy: A design for action researcher collective self-development. Action Learning Action Research Journal, 21 (1): $1-22$.

Dei, G. J. S. (2012). 'Suahunu,' the trialectic space. Journal of Black Studies, 43 (8): 823-846.

Denzin, N. K., \& Giardina, M. D. (2007). Introduction: ethical futures in qualitative research. In N. K. Denzin \& M. D. Giardina (Eds.), Ethical Futures in Qualitative Research: Decolonizing The Politics of Knowledge (pp. 9-44). Walnut Creek CA: Left Coast Press.

Denzin, N. K., \& Lincoln, Y. S. (2008). Introduction: Critical Methodologies and indigenous inquiry. In N. K. Denzin, Y. S. Lincoln, \& L. T. Smith (Eds.), Handbook of critical and indigenous methodologies (pp. 1-20). Thousand Oaks, CA: Sage.

Flood, R. L. (2010). The relationship of systems thinking to action research. Systemic Practice and Action Research, 23 (4): 269-284.

Flood, R. L., \& Romm, N. R. A. (2018). A systemic approach to processes of power in learning organisations: part I - literature, theory, and methodology of triple loop learning. The Learning Organization, 25 (4): 260-272.

Gallagher, M. (2008). 'Power is not an evil': Rethinking power in participatory methods. Children's Geographies, 6(2): 137-150. 
Gergen, K. J. (2009). Relational being. Oxford: Oxford University Press.

Gergen, K. J. (2015). From mirroring to worldmaking: Research as future forming. Journal for the Theory of Social Behavior, 45 (3): 287-310.

Hill, M. (2006). Children's voices on ways of having a voice: Children's and young people's perspectives on methods used in research and consultation. Childhood, 13 (1): 69-89.

Jones, O. (2008). True geography [ ] quickly forgotten, giving away to an adult-imagined universe: Approaching the otherness of childhood. Children's Geographies, 6 (2): 195212.

Kovach, M. (2009). Indigenous methodologies: Characteristics, conversations, and contexts. Toronto: University of Toronto Press.

Kuntz, A. M. (2015). The responsible methodologist: Inquiry, truth-telling, and social justice. Walnut Creek, CA: Left Coast Press.

Le Grange, L. (2018). What is (Post)qualitative research? South African Journal of Higher Education, 32 (5): 1-14.

Lincoln, Y. S., \& Guba, E. G. (2013). The constructivist credo. Walnut Creek, CA: Left Coast Press.

McIntyre-Mills, J. J. (2014a). Systemic ethics and non-anthropocentric stewardship. New York, NY: Springer.

McIntyre-Mills, J. J. (2014b). Transformation from Wall street to wellbeing. New York, NY: Springer.

McIntyre-Mills, J. J. (2017). Planetary passport: representation, accountability and regeneration. New York, NY: Springer.

Mertens, D. M. (2010). Transformative mixed methods research. Qualitative Inquiry, 16(6): 469-474.

Mertens, D. M. (2019). Preface: Transformative mixed methods in troubling times. In J. J. McIntyre-Mills \& N. R. A. Romm (Eds.), Mixed methods and cross-disciplinary research (pp. xi-xviii). Cham: Springer.

Midgley, G. (2001). Systems thinking for the 21st century. In G. Ragsdell \& J. Wilby (Eds.), Systems thinking for the 21st century: Understanding complexity (pp. 249-256). New York, NY: Kluwer Academic/Plenum.

Msila, V. (2017). Heutagogy, Africanization and Learning. In M. T. Gumbo \& V. Msila (Eds.), African voices on indigenization (pp. 45-65). Wandsbeck: Reach Publishers.

Nicholls, R. (2009). Research and indigenous participation: Critical reflexive methods. International Journal of Social Research Methodology, 12 (2): 117-126.

Nkoana, E. M. (2019). Exploring the mismatch between development cooperation's climate adaptation tools and climate change management in local communities in the global South. University of Antwerp: Institute of Environmental and Sustainable Development.

Osuji, P. (2018). Laudato Si' and traditional African environmental ethics. In G. Magill \& J. Potter (Eds.), Integral ecology: Protecting our common home (pp. 184-208). Newcastle Upon Tyne: Cambridge Scholars Publishing.

Rajagopalan, R., \& Midgley, G. (2015). Knowing differently in systemic intervention. Systems Research and Behavioral Science, 32 (5): 546-561.

Romm, N. R. A. (2001). Accountability in social research. New York, NY: Springer.

Romm, N. R. A. (2015). Reviewing the transformative paradigm: A critical systemic and relational (indigenous) lens. Systemic Practice and Action Research, 28: 411-42

Romm, N.R.A. (2017). Researching Indigenous ways of knowing-and-being”. In P. Ngulube (Ed.), Handbook of research on theoretical perspectives on Indigenous Knowledge Systems in developing countries (pp. 22-48). Pennsylvania: IGI Global publications. 
Romm, N. R. A. (2018). Responsible research practice: Revisiting transformative paradigm in social research. Cham: Springer.

Romm, N. R. A. (2020). Reflections on a post-qualitative inquiry with children/young people: Exploring and furthering a performative research ethics. Forum: Qualitative Social Research, 21(1): Art 6.

Roth, M-W. (2006). Collective responsibility and solidarity. Forum Qualitative Sozialforschung/Forum: Qualitative Social Research, 7 (2), Art. 37.

Rousell, D. \& Cutter-Mackenzie-Knowles, A. (2019). A Systematic review of climate change education: Giving children and young people a 'voice' and a 'hand' in redressing climate change. Children's Geographies, 1-18 (online first).

Shannon, P. (2013). Value-Based social work research. Critical Social Work, 14 (1): 101-114.

Skelton, T. (2008). Research with children and young people: Exploring the tensions between ethics, competence and participation. Children's Geographies, 6 (1): 21-36.

Somerville, M., \& Williams, C. (2015). Sustainability education in early childhood: An updated review of research in the field. Contemporary Issues in Early Childhood, 16 (2): 102117.

Smith, L. T. (1999). Decolonizing methodologies: Research and indigenous peoples. New York, NY: Zed Books.

Spyrou, S., Rosen, R., \& Cook. D. T. (eds.) (2018). Reimagining childhood studies. London: Bloomsbury.

St. Pierre, E. A. (2017). Post qualitative inquiry. In N. K. Denzin \& M. D. Giardina (Eds.), Qualitative inquiry in neoliberal times (pp. 37-47). New York, NY: Routledge.

St. Pierre, E. A. (2019). Post qualitative inquiry in an ontology of immanence. Qualitative Inquiry, 25 (1): 3-16.

Stephens, A., Taket, A., \& Gagliano, M. (2019). Ecological justice for nature in critical systems thinking. Systems Research and Behavioral Science, 36: 3-19.

Ulmer, J. B. (2017). Posthumanism as research methodology: Inquiry in the Anthropocene. International Journal of Qualitative Studies in Education, 30 (9): 832-848. 


\section{Appendix A}

Australian-based 3 scenarios (in relation to CC challenges)

Source: McIntyre-Mills 2014b, pp. 51-52

\section{BUSINESS AS USUAL SCENARIO}

We continue to believe in economic arguments that others believe ignore the social and environmental dimension. We continue to think that our way of life is sustainable and are not prepared to manage the perceived risks of climate change by changing our way of life. We attribute drought, bush fires and floods to one-off unrelated events or natural cycles, and deny that climate change can trigger rising temperatures in some areas and plummeting temperatures in others as melting ice effects the ocean currents. We do not perceive that the sea is used as a dumping ground to the extent that it no longer helps to regulate our climate.

\section{SMALL CHANGES SCENARIO}

People make slow annual progress towards goals which they meet for the benefit of their children and grandchildren. People of all ages and from all walks of life who are able to join up the dots between the economic, social and environmental dimensions help to motivate movement towards a better future. We do not perceive these small changes as being too slow to sustain beyond our grandchildren, or we envisage that something else will happen by then to reverse the current trend.

Governments and non-government organizations take the initiative. They hold workshops to demonstrate how people can make a difference. They listen to the people and help local groups to respond to local challenges. Together they undertake model projects that demonstrate how it will be possible to live differently. They model different ways of thinking and through living the changes show that it is possible to balance individual and collective interests, because we are not selfish nor are we unable to create alternative ways of governing at a regional level.

\section{A SUSTAINABLE FUTURE SCENARIO}

We live in an environment that can support this generation and the next. Housing is affordable and made of sustainable materials. We have faced up to the convergent social, economic and environmental challenges and we are resilient, because we live in clusters of homes, share rain tanks and solar grids that are subsidized by local governments. Our living and working areas are powered by alternative energy. The new status symbol is the environmentally friendly lifestyle. Public transport is green. Off road vehicles are no longer permitted to private citizens. They can be hired for specific tasks and the kilometres are logged. The green economy supports a vibrant job market spurred by subsidies to enable packaging goods, housing people, and transporting people, educating and entertaining the public. The carbon economy is replaced through innovative inventions. All members of the public are encouraged to share their experiences and ideas for living sustainably. The futures market has been reconstructed to take into account the air, water and earth we need to grow organic, safe food. We have thought carefully about the implications of treating people, animals and the land as commodities and we strive to care for ourselves, others (including the voiceless) and the land. 